УДК $620.91 ; 624.482$

\title{
ТЕПЛОМАСООБМІННІ ПРОЦЕСИ В ГЕОТЕРМАЛЬНІЙ ВНУТРІШНЬО- СВЕРДЛОВИННІЙ U-ПОДІБНІЙ ЦИРКУЛЯЦІЙНІЙ СИСТЕМІ ПРИ НЕПЕРЕРВНОМУ ВІДБОРІ ТЕПЛОТИ
}

Кравченко І.П., Кузнєцов М.П., докт. техн. наук

Інститут відновлюваної енергетики НАН Украӥни, вул. Гната Хоткевича, 20а, м. Київ, Украӥна

В статті досліджені тепломасообмінні процеси між оточуючим геотермальну свердловину природним середовищем i двонаправленими потоками рідини у двотрубній внутрішньосвердловинній циркуляційній системі, центральна труба якої встановлена коаксіально відносно обсадної, 3 метою 3'ясування можливості промислового видобування геотермальної теплоти без застосування другої свердловини для утилізації відпрацьованого теплоносія.
В статье исследованы тепломассообменные процессы между окружающей геотермальную скважину природной средой и двунаправленными потоками жидкости в двухтрубной внутрискважинной циркуляционной системе, центральная труба которой установлена коаксиально относительно обсадной, с целью определения возможности промышленной добычи геотермальной теплоты без использования второй скважины для утилизации отработанного теплоносителя.
The article examines the processes of heat and mass transfer between surrounding the geothermal wells natural environment and between bidirectional flow of fluid in the double pipe well of system, a central the tube which is set coaxially with respect of outer, with the aim of to determine the possibility of industrial production of geothermal heat without the use of a second well, absorbing of waste heat transfer agent.

Библ. 3, табл. 2, рис. 2.

Ключові слова: геотермальна енергетика, термальна вода, температура, теплота, родовище, свердловина, циркуляційна система, потік.

$\boldsymbol{B c m y n}$
Гідрогеологічне
середовище території України практично не містить родовищ парогідротерм, які дозволили б видобувати геотермальну теплоту у вигляді водяної пари, для чого не знадобилося б застосовувати, що стали вже класичним, подвійні системи свердловин для видобування і захоронення рідкого теплоносія.

При цьому, не тільки видобування геотермальної енергії, але і розвідки іiі покладів, не кажучи вже про виконання бурових робіт, не ведеться вже більше тридцяти років. Усі, створені в Україні зразки дослідних геотермальних установок, побудовані на свердловинах півсторічного віку. В той же час, як на вироблених, так і на діючих родовищах вуглеводнів, особливо нафти, маються тисячі свердловин, які за координатами співпадають або приурочені до геотермальних ресурсів. Там існують як масиви свердловин, так і окремі, як правило не задіяні видобуванням, свердловини. Для висновку про придатність такої свердловини для геотермального використання достатньо вивчити геологічні паспортні дані на неї, які зберігаються у відповідних геологічних і видобувних підприємствах. Аналізу можливостей такого використання поодиноких геотермальних свердловин і присвячена ця робота.

\section{Постановка задачі}

Передбачається створення внутрішньосвердловинної циркуляційної системи шляхом встановлення додаткової труби на усю глибину свердловини (рис.1), що вже анонсувалось раніше без математичного аналізу [1]. Задачею цього дослідження є математичний аналіз тепломасопереносу у свердловині.

Як видно з рисунку, термодинаміка такої системи надзвичайно складна. По-перше, на неї діє 


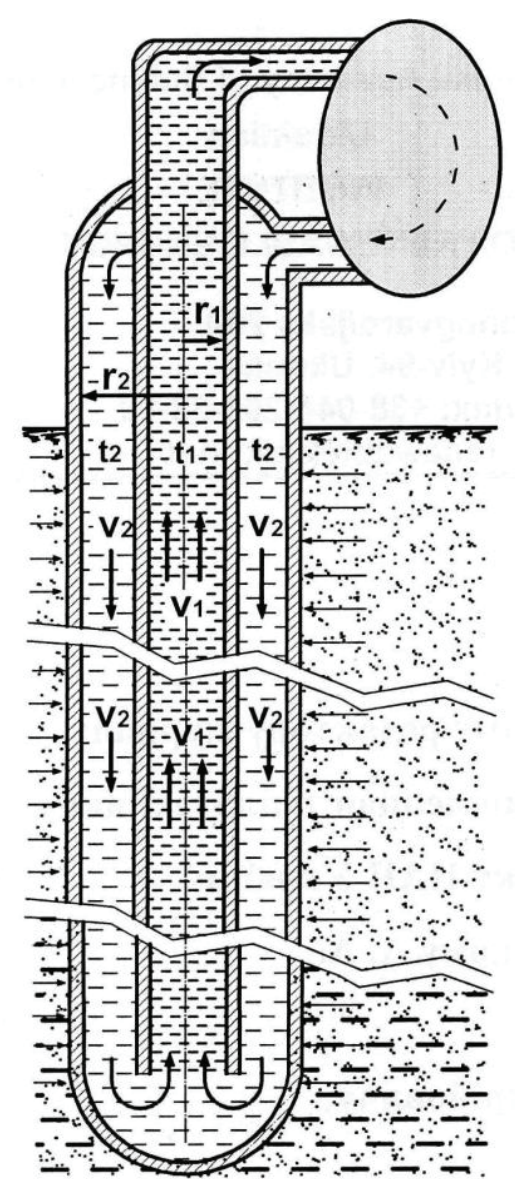

\section{Рис. 1. Внутрішньо-свердловинна циркуляційна система.}

Ілюстрація до методики і математичної моделі визначення параметрів тепломасообміну між потоками рідини $\boldsymbol{i}$ оточуючим середовищем.

теплове поле оточуючого середовища, яке має надзвичайно велику теплову ємність як щодо відбору із свердловини теплоти, так і щодо насичення іiі теплотою в залежності від конкретної точки прикладання цього впливу за глибиною і, відповідно, за температурою усіх складових системи у цій точці.

Таким чином, для визначення координат таких точок за глибиною позначимо цю вісь через $Z$, а фізичні відстані за нею будемо позначати індексом $l$. Радіуси труб позначимо через $R_{l}$ для внутрішньої труби і $R_{2}$ - для зовнішньої труби. Швидкості руху рідини у цих трубах позначимо відповідно через $V_{1}$ i $V_{2}$ (надалі ці індекси позначаються малими літерами). Визначаємо гідродинаміку системи таким чином: вода, нагріта природним середовищем, піднімається догори по центральній трубі зі швидкістю $v_{1}$, де через теплообмінне устаткування віддає частину теплоти споживачу, а потім по міжтрубному простору опускається донизу зі швидкісю $v$, i у самому низу знову міняє напрямок руху. Задачею цього дослідження $є$ з'ясування величин приросту і втрат водою температури при досягненні найвищої і найнижчої точок у свердловині та пов'заних 3 нею витрат рідини, або дебіту, за одну добу.

Оскільки ця методика передбачає ручне фізико-математичне визначення усіх термодинамічних чинників без використання складних комп'ютерних програм та носить оціночний характер, для спрощення приймаємо, що радіуси труб і швидкості в трубах відносяться як $v_{2}=\frac{R_{1}^{2}}{R_{2}^{2}-R_{1}^{2}} v_{1}$, а площі поперечного перетину обох потоків $S_{1}=S_{2}$ рівні між собою. Крім того, на першому етапі вважаємо центральну трубу теплонепрониклою або достатньо теплоізольованою.

За умови усталеної швидкості рідини та усталених теплофізичних параметрах диференційне рівняння, що описує температурне поле теплоносія у внутрішній трубі має вигляд [2]:

$\frac{1}{R} \frac{\partial}{\partial R} R \frac{\partial t_{1}}{\partial R}+\frac{\partial^{2} t_{1}}{\partial Z^{2}}+\frac{v_{1}}{a} \frac{\partial t_{1}}{\partial Z}=0$.

Задаємо граничні умови:

$\left.\lambda \frac{\partial t_{1}}{\partial R}\right|_{R=R_{1}}=-\alpha\left(t_{1}-t_{2}\right),\left.\quad \frac{\partial t_{1}}{\partial R}\right|_{R=R_{0}}=0,\left.\quad \frac{\partial t_{1}}{\partial z}\right|_{z=0}=0$.

Диференційне рівняння, що описує температурне поле теплоносія у зовнішній трубі:

$\frac{1}{R} \frac{\partial}{\partial R} R \frac{\partial t_{2}}{\partial R}+\frac{\partial^{2} t_{2}}{\partial Z^{2}}-\frac{v_{2}}{a} \frac{\partial t_{2}}{\partial Z}=0$.

Відповідно граничні умови:

$t_{2}(R, 0)=t_{0},\left.\lambda \frac{\partial t_{2}}{\partial R}\right|_{R=R_{2}}=-\alpha_{2}\left(t_{2}-t_{\tilde{n}}\right)$,

$\left.\lambda \frac{\partial t_{2}}{\partial R}\right|_{R=R_{1}}=-\alpha\left(t_{1}-t_{2}\right),\left.\frac{\partial t_{2}}{\partial z}\right|_{z=0}=0 \quad t_{1}\left(R_{1}, l\right)=t_{2}\left(R_{1}, l\right)$ 
(оскільки $t_{c}>t_{2}, t_{1}>t_{2}$ i при зростанні $R$, в точці $R=R_{1}$ температура $T_{2}$ зменшується, а при $R=R_{2}-$ зростає),

де $t_{c}$ - температура середовища (гірського масиву) навколо свердловини,

$z$ - відстань (глибина), $(z \leq l, l-$ відстань, на якій потік змінює напрямок руху).

Оскільки зміна температури в радіальному перетині нехтовно мала, можна усереднити іiі за радіусами $R$. Зінтегруємо рівняння (1) за R в межах $\left[0, \mathrm{R}_{1}\right]$, а рівняння (2) за $\mathrm{R}$ в межах $\left[\mathrm{R}_{1}, \mathrm{R}_{2}\right]$. Позначимо $T=\bar{T}(z)$ - температура, усереднена по радіусу.

3 граничних умов випливає:

$$
\begin{aligned}
& \left.R \frac{d T_{1}}{d R}\right|_{R_{0}} ^{R_{1}}=-R_{1} \frac{\alpha}{\lambda}\left(T_{1}-T_{2}\right), \\
& \left.R \frac{d T_{2}}{d r}\right|_{R_{1}} ^{R_{2}}=\frac{R_{1}}{\lambda} a\left(T_{1}-T_{2}\right)-\frac{R_{2}}{\lambda} a_{2}\left(T_{2}-T_{c}\right) .
\end{aligned}
$$

3 урахуванням, що $R_{2}^{2}-R_{1}^{2}=\frac{R_{1}^{2} v_{1}}{v_{2}}$, при розмірностях $\frac{a}{\lambda}=\frac{1}{i} ; \frac{v}{a}=\frac{1}{i}$, в квазістаціонарному випадку таке усереднювання переносить граничні умови на поверхнях циліндрів безпосередньо до диференційних рівнянь:

$$
\begin{aligned}
& \frac{d^{2} T_{1}}{d z^{2}}+\frac{v_{1}}{a} \frac{d T_{1}}{d z}-\frac{2 \alpha T_{1}}{\lambda R_{1}}+\frac{2 \alpha T_{2}}{\lambda R_{1}}=0, \\
& \frac{d^{2} T_{2}}{d z^{2}}-\frac{v_{2}}{a} \frac{d T_{2}}{d z}-\frac{2 v_{2}}{\lambda R_{1} v_{1}} \cdot \frac{\alpha_{2} R_{2}}{R_{1}}\left(T_{2}-T_{C}\right)+\frac{2 v_{2} \alpha}{\lambda R_{1} v_{1}}\left(T_{1}-T_{2}\right)=0 .
\end{aligned}
$$

\section{Вирішення задачі}

Оскільки даний аналіз носить оціночний характер, виконаємо його за спрощеним варіантом, коли внутрішня труба теплоізольована і іiі коефіцієнт тепловіддачі $\alpha=0$. Це означає, що температура у внутрішній трубі однакова на усьому відрізку $l: \mathrm{T}_{1}=$ const; $T_{1}=\left.T_{2}\right|_{z=l}$. Виходячи 3 цього, для дослідження тепломасопереносу в міжтрубному просторі достатньо проаналізувати температурне поле в зовнішній трубі, тобто згідно з рівнянням (4):

$$
\frac{d^{2} T_{2}}{d z^{2}}-\frac{v_{2}}{a} \frac{d T_{2}}{d z}-\frac{2 v_{2}}{\lambda R_{1} v_{1}} \cdot \frac{\alpha_{2} R_{2}}{R_{1}}\left(T_{2}-T_{C}\right)=0,
$$

де: $\mathrm{v}_{1}, \mathrm{v}_{2}$ - швидкість руху води, відповідно, у внутрішній та зовнішній трубах (м/сек); $\alpha$ - коефіцієнт температуропровідності (м²/сек); $\mathrm{R}_{1}, \mathrm{R}_{2}$ - радіуси внутрішньої та зовнішньої труб; $\alpha_{2}-$ коефіцієнт тепловіддачі (Вт/м².град);

$\lambda^{2}$ - коефіцієнт теплопровідності (Вт/м·град); $\mathrm{z}$ - глибина (м); z $\in[0, l]$, де $l$ - максимальна глибина;

$\mathrm{T}_{\mathrm{c}}$ - температура середовища навколо свердловини (град.); $\mathrm{T}_{\mathrm{c}} \in\left[\mathrm{T}_{\mathrm{o}}, \mathrm{T}_{\max }\right]$.

Граничні умови для $\mathrm{T}_{2}$ :

$\left.T_{2}\right|_{z=\hat{\imath}}=T_{\hat{\imath}}$ (температура на вході); $\left.\frac{d T_{2}}{d z}\right|_{z=\hat{\imath}}=0 \quad$ (на вході відсутній додатковий підігрів).

Швидкості рідини і радіуси труб пов'язані відношенням:

$V_{2}=\frac{R_{1}^{2}}{R_{2}^{2}-R_{1}^{2}} \cdot V_{1}$.

На більшості розвіданих геотермальних і нафтових родовищ Дніпровсько-Донецької западини температура на дні свердловин, в залежності від глибини свердловини, коливається в межах $+90 \ldots 135{ }^{\circ} \mathrm{C}$, а градієнт іiі квазілінійної зміни в середовищі навколо свердловин, згідно 3 геологічними вимірами, в середньому становить $2.7{ }^{\circ} \mathrm{C} / 100$ м, що можна описати як

$$
\mathrm{T}_{\mathrm{c}}=\mathrm{T}_{\mathrm{o}}+\mathrm{kz} \text {, де } k=T_{\text {max }}-T_{\mathrm{o}} / l .
$$

Зробимо заміну змінної: $x=z / l$, тоді $x \in[0,1]$. Відтак, рівняння температурного поля для $\mathrm{T}_{2}=\mathrm{T}$ матиме вигляд:

$-T^{\prime \prime}+g T+p T=k \cdot x+p T_{0}$,

де: $=\frac{v_{2} l}{a}, p=\frac{2 v_{2} \alpha_{2} R_{2} l^{2}}{\lambda R_{1}^{2} v_{1}}, \kappa=p \cdot k l$ ( $g$ і $p$ величини безрозмірні, $\kappa-$ град).

Граничні умови: $\mathrm{T}(0)=\mathrm{T}_{\mathrm{o}}, \mathrm{T}^{\prime}(0)=0$.

Розв'язок рівняння (5) згідно 3 правилами розв'язання диференційних рівнянь шукаємо у вигляді: $T=C_{1} e^{\mu_{1} x}+C_{2} e^{\mu_{2} x}+A x+B$, де:

$\mu_{1}, \mu_{2}-$ корені квадратного рівняння $-\mu^{2}+\mathrm{g} \mu+\mathrm{p}=0$, тобто $\mu_{1}, \mu_{2}=\frac{g}{2} \pm \sqrt{\frac{g^{2}}{4}+p}$.

Підставивши значення Т в рівняння (5), отримаємо: $A=k l ; B=T_{0}-k l \frac{g}{p}$. 
3 граничних умов:

$$
\left\{\begin{array}{l}
C_{1}+C_{2}+B=T_{0} \\
C_{1} \mu_{1}+C_{2} \mu_{2}+A=0
\end{array}\right.
$$

(6) або $\left\{\begin{array}{l}C_{1}+C_{2}=k l \frac{g}{p} \\ C_{1} \mu_{1}+C_{2} \mu_{2}=-k l\end{array}\right.$.

Якщо $g^{2}>>p$, то наближено можна взяти $\mu_{1} \approx g$ i $\mu_{2} \approx-\frac{p}{g}, \mathrm{i}$ із системи

$\left\{\begin{array}{l}C_{1}+C_{2}=k l \frac{g}{p} \\ -C_{1} g+C_{2} \frac{p}{g}=k l\end{array}\right.$ отримаємо $\quad C_{1}\left(g+\frac{p}{g}\right)=0 \Rightarrow C_{1}=0 ;$

$C_{2}=k l \frac{g}{p}$. Тоді

$T(x)=k l \frac{g}{p} e^{-\frac{p}{g} x}+k l x+T_{0}-k l \frac{g}{p}=T_{0}+k l x-k l \frac{g}{p}\left(1-e^{-\frac{p}{g} x}\right)$,

що 3 урахуванням наведеної граничної умови $T_{1}=\left.T_{2}\right|_{x=1}$ дозволяє визначити температуру води на вході і на виході внутрішньої труби:

$T_{1}=\left.T_{2}\right|_{x=1}=T(1)=T_{\hat{\imath}}+k l-k l \frac{g}{p}\left(1-e^{-\frac{p}{g}}\right)$,

що і с розв'язком поставленої задачі. При цьому зауважимо, що перші два елемента формули (8) $T_{0}+k l=T_{\max }-$ це температура на дні свердловини або точніше - в точці, де потік міняє напрямок руху із спуску на підйом, тобто з кільцевого міжтрубного простору - у внутрішню трубу. Якщо теплообмін з середовищем абсолютний, тобто $\alpha_{2} \rightarrow \infty$, тоді $\mathrm{T}_{1}=\mathrm{T}_{\mathrm{o}}+\mathrm{kl}=\mathrm{T}_{\mathrm{c}}$.

Виконаємо за формулою (8) числові розрахунки для конкретного, розглянутого в розділі 3, Монастирищенського родовища, зокрема його свердловини № 20. Сформуємо геологічні i фізико-технічні вихідні дані без посилання на конкретні джерела, пославшись тільки на їх відомче походження з НГВУ «Чернігівнафтогаз»:
1. Глибина свердловини $z=l$, м -3500 ;

2. Діаметр свердловини D, м -0.146

(радіус $\left.-\mathrm{R}_{2}=0.073\right)$;

3. Температура на дні свердловини $\mathrm{T}_{\max },{ }^{\circ} \mathrm{C}-97.1$; 4. Температурний градієнт по глибині свердловини $\mathrm{k},{ }^{\circ} \mathrm{C} / 100 \mathrm{M}-2.7$;

5. Приймаємо температуру води на поверхні $\mathrm{T}_{\mathrm{o}},{ }^{\circ} \mathrm{C}-10$; 6. Грунти навколо свердловини - піщаники 3 параметрами:

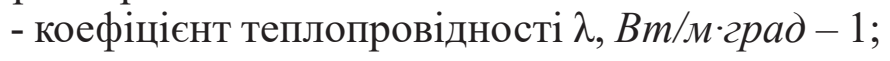

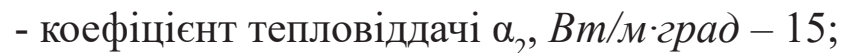

- коефіцієнт температуропровідності $a, M^{2} / 2 о \partial$

$$
-35 \cdot 10^{-4} \text { або } \approx 1 \cdot 10^{-6} \text {. }
$$

7. Приймаємо умову, що швидкості потоків у внутрішній трубі і в міжтрубному просторі рівні між собою v1 = v2 = v, що досягається співвідношенням радіусів труб як $R_{1}=\frac{R_{2}}{\sqrt{2}}$ або рівністю площ перетину кожного 3 потоків. Розрахуєм залежність температури і саму температуру у внутішній трубі, як функцію від швидкості для лінійної швидкості потоків $\mathrm{v}=1 \mathrm{~m} /$ сек, за формулою (8) за кроками:

1). $g=\frac{v_{2} l}{a}=\frac{1 \mathcal{M} / \text { сек } \cdot 3500 \mathcal{M}}{10^{-6} \mathcal{M}^{2} / \text { сек }}=3.5 \cdot 10^{9}$.

2). $p=\frac{2 v_{2} \alpha_{2} R_{2} l^{2}}{\lambda R_{1}^{2} v_{1}}=\frac{2 \cdot 1 M / \text { сек } \cdot 15 \frac{B m}{M^{2} \cdot 2 p a d} \cdot 0.073 M \cdot 3500^{2} M^{2}}{1 \frac{B m}{M \cdot \tau p a d} \cdot 0.052^{2} M^{2} \cdot 1 M / c e \kappa}=$

$$
=9.92 \cdot 10^{9} \approx 10^{10} .
$$

3). Відзначимо: щуо, як видно, $g^{2}>>p$, щзо виправдовує допущення, прийняте при виводi формули (7).
4). $k l \frac{g}{p}=(97.1-10) \cdot \frac{3.5 \cdot 10^{9}}{10^{10}}=30.485 \approx 30.5$.
5). $e^{-\frac{p}{g}}=e^{-2.8} \approx 0.06$.

6). Остаточно:

$T_{1}=T_{o}+k l-k l \frac{g}{p}\left(1-e^{-\frac{p}{g}}\right)=97.1^{\circ} C-30.5^{\circ} C \cdot(1-0.06)=67.52^{\circ} C$.

При тому ж співвідношенні перетину труб i, відповідно, рівності швидкостей у них, але при зменшенні номінального значення швидкості, наприклад, на 10, 20 і т. д. відсотків, ці показники матимуть такі значення (табл. 1.).

Як зміниться температура з часом? Температура середовища навколо свердловини будепадати через відбір тепла водою в іiі міжтрубному просторі. Відповідно тепловий потік від середовища до зовнішньої трубитакож буде падати. Як показано в [2], максимальне зниження температури відбудеться в перші $10 \ldots 15$ діб, а починаючи приблизно з 100-ї доби практично стабілізується і становитиме приблизно 1/4 від початкової величини. 
Табл. 1. Таблиця розрахунків температури води на виході із внутрішньої труби в залежності від іiі швидкості в потоці

\begin{tabular}{|c|c|c|c|c|c|c|c|}
\hline \multirow[b]{2}{*}{$\begin{array}{c}\text { Швидкість } \\
\text { руху води } \\
\text { м/сек }\end{array}$} & \multicolumn{4}{|c|}{ Значення компонент формули (8) } & \multicolumn{2}{|c|}{ Температура $\mathrm{T}_{1}\left({ }^{\circ} \mathrm{C}\right)$} & \multirow{2}{*}{$\begin{array}{c}\text { Квазідебет } \\
\text { води } \\
\text { (витрати) } \\
\text { м.куб./доб. }\end{array}$} \\
\hline & $g=\frac{v_{2} l}{a}$ & $p=\frac{2 v_{2} \alpha_{2} R_{2} l^{2}}{\lambda R_{1}^{2} v_{1}}$ & $\frac{g}{p}$ & $e^{-\frac{p}{g}}$ & $\begin{array}{c}\text { В } \\
\text { першу } \\
\text { добу }\end{array}$ & $\begin{array}{c}\text { Через } \\
185 \\
\text { діб }\end{array}$ & \\
\hline 1 & 2 & 3 & 4 & 5 & 6 & 7 & 8 \\
\hline 1.0 & $3.5 \cdot 10^{9}$ & $810 \cdot 3500^{2}$ & 0.350 & 0.057 & 68.4 & 56.1 & 723.2 \\
\hline 0.9 & $3.15 \cdot 10^{9}$ & $-\ll-$ & 0.315 & 0.042 & 70.8 & & 650.9 \\
\hline 0.8 & $2.8 \cdot 10^{9}$ & $-\ll-$ & 0.280 & 0.028 & 73.4 & & 578.5 \\
\hline 0.7 & $2.45 \cdot 10^{9}$ & $-\ll-$ & 0.245 & 0.017 & 76.4 & & 506.2 \\
\hline 0.6 & $2.1 \cdot 10^{9}$ & $-\ll-$ & 0.210 & 0.008 & 79.0 & & 433.9 \\
\hline 0.5 & $1.75 \cdot 10^{9}$ & $-\ll-$ & 0.175 & 0.003 & 81.9 & & 361.6 \\
\hline 0.4 & $1.4 \cdot 10^{9}$ & $-\ll-$ & 0.140 & $\approx 0$ & 84.9 & & 289.3 \\
\hline 0.3 & $10.5 \cdot 10^{8}$ & $-\ll-$ & 0.105 & $-\ll-$ & 88.0 & & 217.0 \\
\hline 0.2 & $7 \cdot 10^{8}$ & $-\ll-$ & 0.070 & $-\ll-$ & 91.0 & & 144.6 \\
\hline 0.1 & $3.5 \cdot 10^{8}$ & $-\ll-$ & 0.035 & $-\ll-$ & 94.1 & 92.0 & 72.3 \\
\hline
\end{tabular}

Оскільки тепловий потік пропорційний різниці температур, то в 4 рази зменшиться і ця різниця. Отже, якщо при швидкості води в трубі $1 \mathrm{~m} /$ сек максимальний перепад температур між водою i середовищем досягав $30^{\circ}$, то через півроку він становитиме $7^{\circ} \ldots 8^{\circ}$. По відомій формулі [3] за $\tau$ годин температура середовища буде:

$\left.T_{c}(\tau)\right|_{R=R_{2}}=T_{c}(0)-\frac{q R_{2}}{2 \lambda} \ln \frac{4 a \tau}{1.8 R_{2}{ }^{2}}$, де $q=\alpha_{2}\left(T_{c}-T_{2}\right)-$

тепловий потік.

Якщо при попередніх числових даних перепад температур впаде $330^{\circ}$ до $7^{\circ} \ldots 8^{\circ}$, то

$$
\mathrm{T}_{\mathrm{c}}(\tau)=97.1-3.8 \cdot \tau \cdot \ln (1.4 \tau) .
$$

Через півроку при $\tau=4300$ годин $\left.T_{c}\right|_{R=R_{2}} \approx 97.1^{\circ}-33^{\circ}=64.1^{\circ}$. При цьому температура води $\mathrm{T}_{1}=64.1{ }^{\circ} \mathrm{C}-8{ }^{\circ} \mathrm{C}=56.1{ }^{\circ} \mathrm{C}$, що, 3 урахуванням лінійності результатів, нанесено на графік рис. 2. лінією тільки між цими двома значеннями температур. Вид формули (8) при цьому не змінюємо, але значення $\alpha_{2}$ треба обирати як для нового стану середовища.

Якщо швидкість $v \in$ іншою, наприклад $\mathrm{v}_{1}=0.1 \mathrm{~m} /$ сек, то перепад температур зменшиться $33^{\circ}$ до $0.8^{\circ} \ldots 1^{\circ}$, температура середовища впаде до $93{ }^{\circ} \mathrm{C}$, а води до $92{ }^{\circ} \mathrm{C}$. Розраховані проміжні зна- чення $\mathrm{T}_{1}$ на відрізку швидкостей від $0.1 \mathrm{~m} /$ сек до 1.0 м/сек наведені в колонці 6 таблиці 2.

Викликають великий інтерес ще два варіанта розрахунків, умови в яких відрізняються від розглянутих вище.

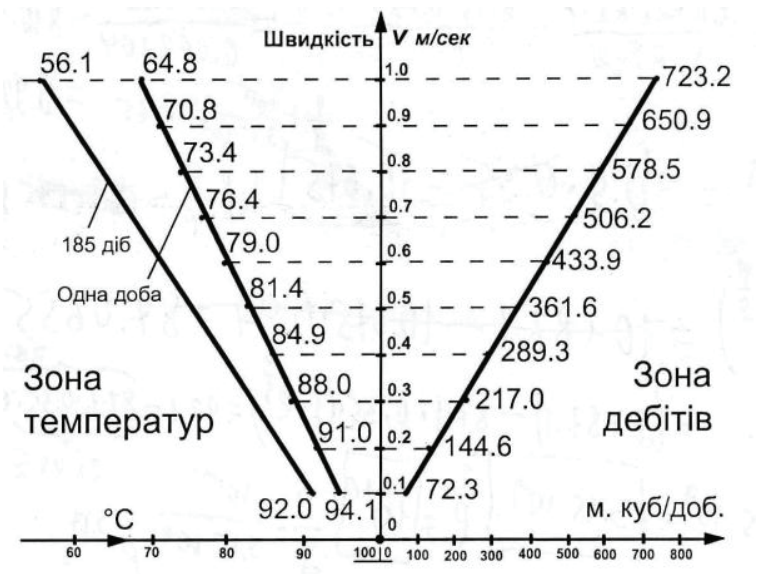

Рис. 2. Графік залежності температури $T_{1}$ води від швидкості її руху $і$ відповідний цій залежності дебет теплоносія на поверхні.

\section{Bapiaнm №1}

Якщо внутрішня труба не $є$ повністю теплонепроникною $(\alpha \neq 0)$, розподіл температур у внутрішньому i зовнішньому потоках $\epsilon$ 
взаємопов'язаним. Розглянемо вихідну систему диференційних рівнянь (3) і (4), записавши іiі у вигляді (з урахуванням введених вище позначень):

$$
\begin{aligned}
& \left\{\begin{array}{l}
T_{1}^{\prime \prime}+g_{1} T_{1}^{\prime}-m p_{1}\left(T_{1}-T_{2}\right)=0 \\
T_{2}^{\prime \prime}+g_{2} T_{2}^{\prime}-p_{2}\left(T_{2}-T_{c}\right)+m p_{1}\left(T_{1}-T_{2}\right)=0
\end{array}\right. \\
& \left(T_{c}=T_{0}+k l x\right)
\end{aligned}
$$

При рівності швидкостей використаємо умову $v_{1}=v_{2}$ та позначимо:

$m=\frac{\alpha_{1} R_{1}}{\alpha_{2} R_{2}}=\frac{\alpha}{\sqrt{2} \alpha_{2}}, g_{1}=g_{2}=g, \quad p_{1}=p_{2}=p$.

3 (9) отримаємо:

$$
\begin{aligned}
& T_{1}=T_{2}+\frac{1}{m p}\left[p\left(T_{2}-T_{c}\right)+g T_{2}^{\prime}-T_{2}^{\prime \prime}\right], \\
& T_{2}^{I V}-T_{2}^{\prime \prime}\left(2 m p+p+g^{2}\right)-T_{2}^{\prime} \cdot g p+m p^{2}=m p \cdot T_{c}-g p \cdot k l .
\end{aligned}
$$

Якщо підставити використані раніше числові значення $\left(\mathrm{g}=3.5 \cdot 10^{9}, \mathrm{p}=10^{10}\right)$, то можна зазначити малість множників при вищих похідних, що дозволяє спростити рівняння (10), знизивши його порядок до 2-го. Оскільки зміна температури вздовж каналу труби відбувається плавно, по закону, близькому до лінійного, то вплив других похідних в рівняннях (9) досить незначний і їх можна ігнорувати, спростивши систему до двох рівнянь 1-го порядку при 2-х граничних умовах. Розв'язок (10) матиме вигляд:

$T_{2}=C_{1} e^{\mu_{1} x}+C_{2} e^{\mu_{2} x}+T_{c}$ при граничних умовах $\left.T_{2}\right|_{x=0}=T_{0},\left.T_{2}\right|_{x=1}=\left.T_{1}\right|_{x=1}$.

Звідси

$\mu_{1}, \mu_{2}=-\frac{p}{g}\left( \pm \sqrt{\frac{1}{4}+m}+\frac{1}{2}\right)$ визначається як розв'язок характеристичного рівняння $\mu^{2}+\frac{p}{g} \mu-m \frac{p^{2}}{g^{2}}=0 ; C_{-}=-C_{2}=C ; \quad\left(\mu_{1}<0, \mu_{2}>0\right)$.

Константу $C$ визначаємо з рівняння:

$C\left[\frac{g}{p}\left(\mu_{1} e^{\mu_{1}}-\mu_{2} e^{\mu_{2}}\right)+\left(e^{\mu_{1}}-e^{\mu_{2}}\right)\right]=-k l \frac{g}{p}$.

Цей вираз можна спростити, якщо врахувати, що $e^{\mu_{1}}\left[<<\cdot e^{\mu_{2}}\right.$ при $\mathrm{m}>>0$,

$$
C\left(1+\frac{g}{p} \mu_{2}\right)=k l \frac{g}{p} e^{-\mu_{2}}
$$

Враховуючи, що $k l=87.1^{\circ}$, розглянемо вплив величини $m=\frac{\alpha}{\sqrt{2} \alpha_{2}}$ на температуру води на вході та виході внутрішньої труби, тобто $T_{1}(1)$ та $T_{1}(0)$ :

$$
\begin{aligned}
& T_{1}(1)=T_{2}(1)=T_{0}+k l-C e^{\mu_{2}}, \\
& T_{1}(0)=\frac{g}{m p}\left[C\left(\mu_{1}-\mu_{2}\right)+k l\right]+T_{0},
\end{aligned}
$$

де С визначається з (12).

Практичний розрахунок температур на вході і виході внутрішньої труби виконаємо для чотирьох не нульових значень т та порівняємо їх 3 попереднім результатом, коли $m=0$. Результати розрахунків наведені в таблиці 2:

Табл. 2. Розрахунки $T_{1}$ в залежності від значення $m$ у межах $0 \leq m \leq 10$

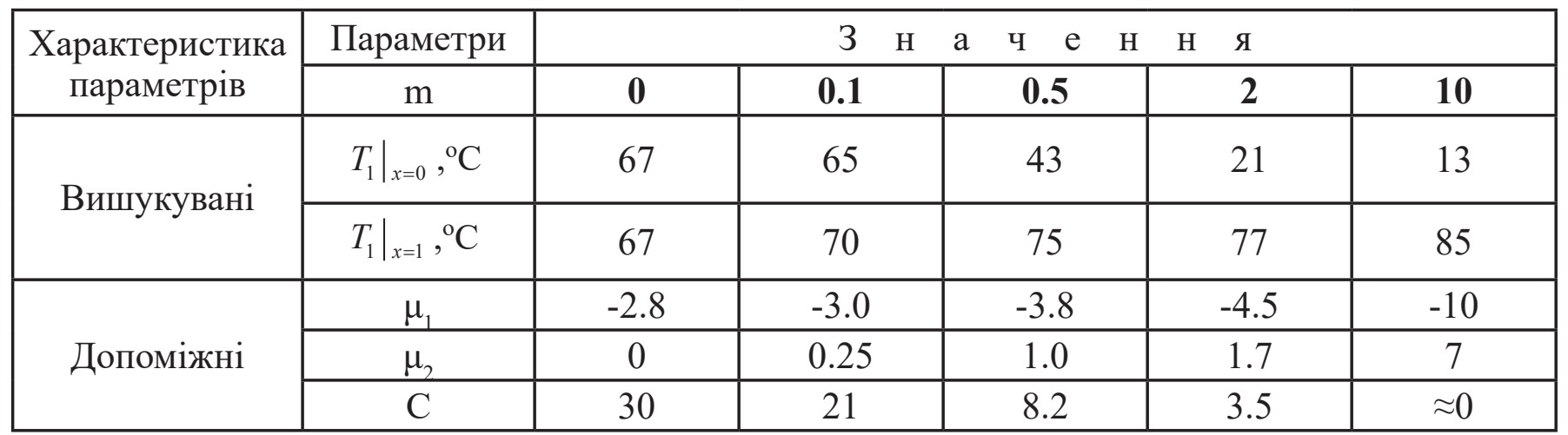

Таким чином, наявність теплопровідності у внутрішньої труби спричиняє дужчий підігрів води в міжтрубному просторі за рахунок відтоку теплоти з внутрішньої труби, через що вихідна вода 3 неї значно охолоджується. При високій теплопровідності вода у внутрішній трубі майже не нагрівається. Відбувається тільки внутрішній теплообмін між потоками. 


\section{Bapiaнm №2}

Усі, розглянуті вище, геотермічні розрахунки відносилися до умов, коли гірське середовище навколо свердловини є піщаниками з параметрами, наведеним у п.6 вище, і отримувана в розрахунках температура $T_{1}$ відносилася до точки $z$ у свердловині, де потік міняє напрямок руху, тобто відразу переходить 3 міжтрубного простору у центральну трубу.

У реальної свердловини № 20 Монастирищенського родовища, щодо якого здійснені тут усі розрахунки, останні 31.6 метрів являють собою потужний, заводнений термальною водою, горизонт $з$ температурою по усій товщі 31.6 м рівною 97,1 ${ }^{\circ} \mathrm{C}$. До речі, таке явище притаманне більшості родовищ як нафти, так і газу, які приурочені до термоводоносних шарів оточуючого їх гірського середовища.

Розрахуємо величину добавки температури до води у свердловині № 20, яка надійшла по міжтрубному простору і пройшла через усю товщу термоводоносного горизонту. Що змінилося в умовах нової задачі? Те, що на протязі усього нового значення $l$ температура середовища $T_{c} \epsilon$ незмінною і конкретно рівна $97,1{ }^{\circ} \mathrm{C}$. Вважаємо, що теплоємність усього гірського масиву i вміщеного в нього термоводоносного горизонту навколо свердловини є настільки енергоємним, що відбір теплоти рухомим циліндричним шаром води діаметром 0.146 м 3 товщиною стінки усього 0.02 м не здатний відчутно вплинути на його параметри. При цьому необхідно встановити нові значення параметрів для розрахунків, які змінилися $з$ появою водного середовища навколо свердловини:

- висота відрізку свердловини 1, м - 31.6;

- коефіцієнт тепловіддачі $\alpha_{2}, B m / \mathrm{M}^{2}$ гррад - $300^{*}$.

* - Таблиия повних коефіuієєнтів теплообміну містить значення $\alpha_{2}$ для систем «Рідини всередині $i$ зовні труб» (wwwltehtab.ru) в межах $150 \ldots 1200 \mathrm{Bm} / \mathrm{m}^{2}$ град. Тут вибране значення в розмірі 1/4 від максимальної з огляду на фільтрацію рідини, щзо оточує свердловину, не в порожнині, а в пористому середовищі. При ігноруванні впливу скелету породи ией показник значно вищиий.
Скористаємося другим диференційним рівнянням з системи (9), за яким виконували попередні розрахунки:

$T_{2}^{\prime \prime}+g_{2} T_{2}^{\prime}-p_{2}\left(T_{2}-T_{c}\right)+m p_{1}\left(T_{1}-T_{2}\right)=03$ урахуванням; що у цьому випадку $m=0$, та нехтуючи старшою похідною:

$g_{2} T_{2}^{\prime}+p_{2}\left(T_{2}-T_{c}\right)=0$

але 3 граничною умовою $T_{0}=T_{2}(0)=\left.T_{2}\right|_{z=l}$. Тобто, початкова температура дорівнює досягнутому значенню на глибині $l$. Натомість, в зовнішньому шарі товщиною $l_{l}$ температура практично незмінна: $T_{c}=T_{\max }$. Тоді розв'зок рівняння (13)

матиме вигляд:
$T_{2}(x)=C_{1} e^{\mu x}+C_{2}$, або $T_{2}(x)=T_{c}-\left(T_{c}-T_{0}\right) e^{-\frac{p_{2}}{g_{2}} x}$.

Тут $z \in\left[0, l_{1}\right]$, тобто $x \in[0,1], z=x l_{1}$.

При розрахунку $g_{2}$ i $p_{2}$ враховуємо умови теплопередачі в термоводоносному шарі, які відповідають його фізичним властивостям. Оцінимо величину такої добавки для розглянутого вище значення $v_{1}=v_{2}=v=1 \mathrm{~m} /$ сек (колонка 6 таблиці 1):

$T_{o}=67.5^{\circ} \mathrm{C}, \quad T_{\max }=97.1^{\circ} \mathrm{C}, \quad l_{l}=31.6 \mathrm{M}$, $\alpha_{2}=300 \mathrm{Bт} / \mathrm{M}^{2}$ град.

$\frac{p}{g}=\frac{4 \alpha_{2} a l}{v \lambda R_{2}}=\frac{4 \times 300 \times 10^{-6} \times 31.6}{1 \times 1 \times 0.073}=\frac{0.03792}{0.073}=0.52 ;$

$T_{2}(1)=97.1-29.6 \times e^{-0.52}=97.1-29.6 \times 0.594=79.52 \approx 79.5$.

Тобто, при проходженні кільцевого міжтрубного потоку ще 31.6 м зі швидкістю 1 м/сек, вода підігріється на 79.5-67.5 = 12.0 градусів.

При швидкості ж 0.1 м/сек добавка значення температури становитиме:

$\frac{p}{g}=\frac{4 \alpha_{2} a l}{v \lambda R_{2}}=\frac{4 \times 300 \times 10^{-6} \times 31.6}{0.1 \times 1 \times 0.073}=\frac{0.03792}{0.0073}=5.19 ;$

$T_{2}(1)=97.1-29.6 \times e^{-5.19}=97.1-29.6 \times 0.0056=97.1-0.17=96.93$.

При такій швидкості вода практично прийме температуру оточуючого середовища i при використанні теплоізольованої внутрішньої труби досягне поверхні з температурою реального геотермального флюїду.

\section{Висновки}

1. При застосуванні внутрішньосвердловинних технологій видобування i аку- 
мулювання теплової енергії, позитивний ефект досягається тільки за умови теплоізоляції внутрішньої труби. Певним винятком є тільки умова, якщо свердловина явно геотермальна, тобто вона закінчується термоводоносним горизонтом 3 температурою флюїду, що відповідає геотермічному градієнту температури, відносно якого ведеться проектування геотермального водозабору.

2. При проектуванні такої системи необхідно враховувати взаємну залежність дебету і температури, яка визначається швидкістю руху рідини у міжтрубному просторі системи (графік рис. 2). Розрахунок параметрів тепломасообміну при нерівних між собою площах перетину потоків $S_{1} \neq S_{2}$ і, відповідно, нерівністю між швидкостями $v_{1} \neq v_{2}$ в потоках, не ставився в даній оціночній задачі.

3. При створенні внутрішньо-свердловинних циркуляційних систем доцільно надавати перевагу родовищам, глибина буріння на яких перевищує 3500 метрів, а в ідеалі - на рівні
$4500 \ldots 5000$ метрів з огляду на природну температуру на їхній максимальній глибині (120 і більше градусів за Цельсієм).

4. При створенні внутрішньо-свердловинних циркуляційних систем доцільно надавати перевагу свердловинам, які пронизують термоводоносні горизонти, особливо у своїй найнижчій ділянці.

\section{ЛІТЕРАТУРА}

1. І. П. Кравченко. Перспективи розвитку в Україні геотермальних гібридних тепло-технологій на вироблених нафтових i газових родовищах// Відновлювана енергетика, №4(43), - 2015, Київ. C. $60-66$

2. Ю. П. Морозов. Эффективность извлечения теплоты горного массива путём использования буровой скважины//Альтернативная энергетика и экология, Саров, 2014. - №23(163), С. 49-52.

3. Лебедев Н. Н. Сборник задач по математической физике /Лебедев Н.Н., Скальская И.П., Уфлянд Я.С., Государственное изд. технико-теоретической литературы, М., -1955 г. - 420 с. 
PROCESSES OF HEAT AND MASS TRANSFER IN GEOTHERMAL U-SHAPED CIRCULATION SYSTEM AT CONTINUOUS OF THE HEAT REMOVAL

\section{Kravchenko I.P., Kuznetcov M.P.}

Institute of Renewable energy of the National Academy of Sciences of Ukraine, vul. Hnata Khotkevicha, 20A, Kyiv, 02094, Ukraine

In hydrogeological environment in Ukraine almost no deposits of heat steams that can produce geothermal energy, which was not necessary to apply dual system of wells for the extraction and disposal of liquid coolant. In addition, in Ukraine no not only the extraction of geothermal energy, but the exploration of deposits, not to mention of drilling operations, not made more than thirty years. At the same time, in the deposits of hydrocarbons, particularly petroleum, have thousands of freed wells, coordinates which coincide with geothermal resources. The conclude on the suitability of such geothermal wells can if study geological passport data, which stored in geological and mining enterprises. To analysis such capabilities use single geothermal wells dedicated ritherch in to this work.

Supposed making of circulation system by installing additional coaxial of pipe to the entire depth of the well (Figure 1), about which was announced earlier without mathematical analysis [1]. The object of this research is the mathematical analysis of heat and mass transfer in the well.
As a result of mathematical operations with the system of differential equations that describe the temperature field in the inner and outer tube, received one working differential equations. The solution of this equation yielded the following result: extract geothermal heat transfer fluid using such a system is possible only if the inner tube nonconductor heat. Even so, temperature of water on the surface depends on the speed of its pumping by the annulus (Figure 2).

In summary it is concluded that the production of geothermal energy in this way is suitable at depths wells deeper 3,500 meters and temperature at their bottom more than 100 degrees Celsius.

References 3, tables 2, figures 2 .

Key words: geothermal energy, thermal water, temperature, heat, well, circulation systems, flow.

1. Kravchenko I.P. Perspektivi rozvitku v Ukrainy heothermalnih gibrinih theplotehnologiy na viroblenih naftovih I gasovih rodovishchah // Vidnovluvana energetika, №4(43), 2015, Kyiv, P. 60-66;

2. Morozov Y.P. Effektivnost izvlechenija teploty gornogo massiva putiom ispolzovanija burovoy skvaziny// Alternativnaja energetika i ecologyja, Sarov, 2014, №23 (163), pp. 49-52.

3. Lebedev N.N. Sbornik zadach po mathematicheskoy physiky / Lebedev N.N., Skalskaya I.P., Uflyand Y.S., State ed. technical and theoretical Literature, Moscow, 1955, 420 p.

Получено 02.08.2016

Received 02.08.2016 